Review

\title{
Pituitary-Adrenal Axis in Prader Willi Syndrome
}

\author{
Olivia S. Edgar, Angela K. Lucas-Herald and Mohamad Guftar Shaikh * \\ Received: 17 December 2015; Accepted: 12 January 2016; Published: 19 January 2016 \\ Academic Editor: Danny Camfferman \\ Developmental Endocrinology Research Group, Royal Hospital for Children, University of Glasgow, \\ 1345 Govan Road, Glasgow G41 4TF, UK; 1107167e@student.gla.ac.uk (O.S.E.); \\ angelalh@doctors.org.uk (A.K.L.-H.) \\ * Correspondence: guftar.shaikh@nhs.net; Tel.: +44-0141-201-1100
}

\begin{abstract}
Purpose: Prader Willi syndrome (PWS) is a rare genetic condition that has concurrent endocrinological insufficiencies. The presence of growth hormone deficiency has been well documented, but adrenal insufficiency (AI) is not widely reported. A review was conducted to investigate its prevalence and relevance in PWS in both adults and children. Methodology: A literature review was performed with the search terms "Prader-Willi syndrome" and "adrenal insufficiency". Results: The review found studies disagree on the prevalence and method of investigation of AI in PWS. Case studies demonstrate that patients with PWS are at risk of premature death, often secondary to respiratory infections. The possibility that this may be the result of the inability to mount an effective cortisol response has been studied, with some evidence confirming AI in PWS patients. Most reports agreed AI is present in PWS, however, Farholt et al. showed no HPA axis dysfunction in adults, suggesting that perhaps it is rare in adults, and children should be the focus of further studies. Conclusion: AI is present in some patients with PWS. Further research is required to ensure optimal treatment can be implemented and to prevent premature deaths related to adrenal insufficiency. Clinicians should have a low threshold for testing the adrenal axis and considering treatment for adrenal insufficiency in PWS patients.
\end{abstract}

Keywords: adrenal; steroid; hydrocortisone; PWS

\section{Introduction}

Prader Willi syndrome (PWS) was first described in 1956 [1]. It is a genetic condition, usually secondary to a deletion of a segment of the paternally-inherited chromosome 15q11-q13, although other genetic abnormalities have been described, including maternal uniparental disomy of the same chromosome [2]. PWS is rare with a UK prevalence estimated to be around 1:52,000 and a birth incidence of approximately 1:29,000 [3]. The prevalence appears to be rising but this could be due to increasing awareness of the syndrome and increased diagnosis in paediatric care [4].

The different manifestations of PWS vary with age, but not gender [5]. Affected infants initially present with feeding problems due to hypotonia and a poor suck, and the condition, in fact, represents $11 \%$ of children under the age of two years presenting with hypotonia [6]. From the age of two years the clinical features are dominated by increasing weight gain, hyperphagia, and an insatiable appetite. Other features include short stature, learning difficulties, dysmorphic facial features, low lean body mass, hypogonadism, and sleep and behavioural disturbance [2,7]. The endocrine features of PWS are well recognised and can include Growth Hormone Deficiency (GHD) or insufficiency, cryptorchidism and hypogonadism, hypothyroidism, impaired glucose tolerance and diabetes mellitus [2]. Short term treatment with recombinant growth hormone (GH) for children with PWS was first reported in 1987 and PWS has since become a licensed indication for its use [8]. 
A less well studied aspect of PWS is the occurrence of adrenal insufficiency (AI). AI is the impaired production of cortisol or action of ACTH, including unresponsiveness of the adrenals to ACTH [9]. Although AI was not included in the original descriptions of PWS, more recent studies have proposed it as a possible additional feature.

To determine the importance of AI in patients with PWS, we performed a literature search with Pubmed and Google Scholar using the terms "Prader Willi syndrome" and "adrenal insufficiency" (AI), with the aim to consider current literature regarding the frequency and significance of adrenal insufficiency in patients with PWS.

\section{Why Could AI Be an Issue in PWS?}

Studies have demonstrated that PWS is associated with a high rate of sudden unexpected death at $3 \%[3,10]$, although these have been limited by their small sample size. As GH therapy has been introduced in recent years, there have been some concerns that there could be an association between GH therapy and sudden unexplained death in PWS. Nagai et al. [11], therefore, performed a post mortem study on 13 patients who had not received GH therapy and seven who had. They found that cause of death tended to correlate with age and stage of development rather than with GH treatment. Young infants (0-1 year) typically died of milk aspiration secondary to hypothalamic dysregulation of respiratory function. Young children and adolescents (1-19 years) died from complications of respiratory infections, while young adults ( $\geqslant 20$ years) died from the complications of obesity and diabetes mellitus [11]. Tauber et al. [12] undertook a similar study, but had a larger cohort of 64 patients. Again, respiratory disorders were the most common cause of death (COD) (61\%) and GH therapy had no correlation with increased death rate [12]. Table 1 summarises papers which report the cause of death in patients with PWS.

Table 1. Cause of death in patients with PWS-summary of reports.

\begin{tabular}{|c|c|c|c|}
\hline Author(s) & Patients & Method & Results: Cause of Death \\
\hline $\begin{array}{l}\text { Schrander-Stumpel et al., } \\
2004 \text { [13] }\end{array}$ & $\begin{array}{l}27 \text { PWS patients who died } \\
\text { (age range birth-8 years) }\end{array}$ & $\begin{array}{l}\text { Case reports } \\
\text { reviewed after death }\end{array}$ & $\begin{array}{l}\text { Four cases of early morning sudden } \\
\text { unexplained death in context of } \\
\text { infectious symptoms }\end{array}$ \\
\hline Stevenson et al., 2004 [14] & $\begin{array}{l}\text { Eight patients with PWS } \\
\text { who died, ages } \\
5 \text { months }-42 \text { years }\end{array}$ & $\begin{array}{l}\text { Case reports } \\
\text { reviewed after death }\end{array}$ & $\begin{array}{l}\text { Three patients had hypoplastic adrenal } \\
\text { glands at time of postmortem }\end{array}$ \\
\hline Van Vliet et al., 2004 [15] & $\begin{array}{l}1 \text { PWS patient who died } \\
\text { aged four years }\end{array}$ & $\begin{array}{l}\text { Case report reviewed } \\
\text { after death }\end{array}$ & $\begin{array}{l}\text { Likely sleep apnoea and tonsillar } \\
\text { hypertrophy resulting in sudden death }\end{array}$ \\
\hline Vogels et al., 2004 [4] & $\begin{array}{l}78 \text { patients with PWS } \\
\text { (mean age } 26 \text { (range } \\
0-56 \text { years) }- \text { - seven died }\end{array}$ & $\begin{array}{l}\text { Data collected from } \\
\text { genetic centers in } \\
\text { Flanders }\end{array}$ & $\begin{array}{l}\text { Sudden respiratory infections with a } \\
\text { high temperature most common. } 1 / 7 \\
(14 \%) \text { patient died of sudden } \\
\text { collapse-cause unknown }\end{array}$ \\
\hline Nagai et al., 2005 [11] & $\begin{array}{l}13 \text { PWS patients who had } \\
\text { received GH therapy and } \\
\text { seven who had not }\end{array}$ & Post mortem study & $\begin{array}{l}\text { Dependent on age group; young } \\
\text { infants (milk aspiration due } \\
\text { dysregulation of respiratory function). } \\
\text { Young children (complications of } \\
\text { respiratory infections). Teenagers and } \\
\text { young adults (complications of obesity } \\
\text { and diabetes) }\end{array}$ \\
\hline Tauber et al., 2008 [12] & $\begin{array}{l}64 \text { patients (age range } 1 \\
\text { day-19 years), } 28 \text { on } \\
\text { GH therapy }\end{array}$ & $\begin{array}{l}\text { Study of } \\
\text { post mortem reports }\end{array}$ & $\begin{array}{l}\text { Respiratory causes in } 24(63 \%) \\
\text { including infection and obstruction } \\
\text { secondary to tonsillar hypertrophy. } \\
\text { Sudden death of unknown cause in } \\
11(29 \%)\end{array}$ \\
\hline
\end{tabular}

While the above studies establish a common primary cause of death, they do not fully explore any underlying abnormality which could cause PWS children to be more susceptible to these life-threatening respiratory infections. One possible explanation is an inability to mount an effective 
cortisol response $[10,14]$. This was suggested after a post mortem study on eight individuals with PWS (four infants aged 5-19 months, two toddlers aged 3.5 years, and two adults aged 29 and 43 years) [14]. Four of these individuals had an autopsy that recorded adrenal weight and of these three had well below average adrenal weight for body length. This theorises that there could be an unrecognised peripheral adrenal insufficiency in PWS children perhaps contributing to their deaths [14]. A larger cohort of patients for further studies would be needed, however, to confirm this association.

To further investigate this hypothesis, one study used 3D MRI to review the pituitary gland while simultaneously measuring basal pituitary hormonal levels in patients with PWS [16]. This found a high prevalence of morphological pituitary abnormalities, such as hypoplasia and universal anterior hormone deficiencies in PWS subjects. Although they did not measure ACTH specifically, if other anterior hormones were deficient it is possible that ACTH would be too, although the authors recognise that further studies are needed to explore this [16]. Interestingly this study had both a control group and a group with early onset morbid obesity (EMO). The patients with EMO showed very similar results to those with PWS, which could indicate that the aetiology of this pituitary deficiency may be, in part, secondary to the obesity phenotype of PWS rather than congenital in nature, or may be just normal variation.

In an attempt to explain the high sudden unexpected death rate in children with PWS, studies $[3,10]$ have postulated that PWS patients may be unable to mount an appropriate cortisol response during stressful conditions, such as infection. Physiological stress, often induced by critical illness, results in an acute and prolonged response of the HPA axis, causing an increase in plasma cortisol and ACTH levels [17].

In 2008, de Lind van Wjingarden et al. [10] studied 25 randomly-selected PWS patients in a paediatric intensive care unit (PICU), and used overnight single-dose metyrapone testing to measure ACTH response alongside 11-deoxycortisol, cortisol and glucose levels. The median age was 9.7 (range 6.8-13.6) years. Diurnal salivary cortisol profiles were also assessed on an alternative day to when the patients were receiving metyrapone. Central AI was confirmed if the ACTH response was $33 \mathrm{pmol} / \mathrm{L}$ at $0730 \mathrm{~h}$. They found that 15 patients $(60 \%)$ fulfilled the criteria of AI, however salivary cortisol levels were normal in all patients, suggesting that AI only became apparent in induced stressful conditions [10] and might offer an explanation for the high death rate from stress-related illnesses.

Following this study, two further studies were carried out to see if this level of AI was replicated [18,19]. Corrias reviewed the adrenal responses of 84 PWS patients in a tertiary referral centre. A total of 35 females and 49 males (age range 0.8-17.9 years) were enrolled in the study. The adrenal response of these patients was assessed by measuring morning cortisol and ACTH dosage, using a $1 \mu \mathrm{g}$ synacthen test or low dose short synacthen test (LDSST), and an appropriate response was considered to be more than $500 \mathrm{nmol} / \mathrm{L}$. An LDSST supplies a lower dose of synthetic ACTH than a standard short synacthen test (SST) where 250 micrograms of ACTH is administered. The LDSST, therefore, represents the adrenal cortical response to ACTH administration, with studies suggesting it may be the most reliable test for ACTH deficiency [20,21] as the LDSST may detect adrenal insufficiency in those who had a normal SST [22], although this is a controversial area as there is no clear evidence that one test is superior to the other. On the low dose synacthen stimulation test 12 patients had unsatisfactory cortisol responses $(14.3 \%)$ with reduced basal $(169.4 \pm 83.3 \mathrm{nmol} / \mathrm{L})$ and stimulated $(428.1 \pm 69.6 \mathrm{nmol} / \mathrm{L})$ cortisol levels [18]. These patients were retested using a standard dose $250 \mu \mathrm{g}$ synacthen test which confirmed AI in four patients $(4.8 \%)$. This result agreed with the study by de Lind van Wjingarden et al. that AI is present in some PWS children. However, the statistics showed it was less prevalent than previously reported [10].

A similar study was conducted as a follow up to the de Lind van Wjingarden paper by Nyunt et al. [19]. This group used a low dose synacthen test (LDSST) (1 $\mu \mathrm{g})$ to screen for AI in 41 PWS children (mean age $7.68( \pm 5.23)$ ) years, and measured ACTH and cortisol levels. This study, however, provided contradictory evidence, as all children demonstrated a normal cortisol response of $\geqslant 500 \mathrm{nmol} / \mathrm{L}[19]$. 
Further contradictory evidence was provided in a study by Farholt et al. Their cohort consisted of 57 participants, 18 under the age of 17 and 39 adults (total median age 22; age range 0.6-48) and, of this cohort, none showed any HPA dysfunction in response to a standard high dose synacthen test or insulin tolerance test. From this we could conclude that not only is this condition rare but perhaps a paediatric issue [23].

Another study that used LDSST on 53 PWS adults to determine the presence of AI [23] showed that eight participants (15.1\%) had an insufficient cortisol response, with a peak cortisol of $<500 \mathrm{nmol} / \mathrm{L}$. These subjects were retested with a high dose short synacthen test (HDSST) and, of the eight, four (7.5\%) had suboptimal responses [24].

The above studies are summarised in Table 2. There is no obvious explanation for the differing results, however the authors have suggested that perhaps the differing test methods or cut off levels could be responsible. Measurement of cortisol using different assays itself has also changed over time with lowering of acceptable cortisol thresholds. There is no current gold standard in terms of the type of test used for AI in PWS or the frequency of monitoring required. To truly understand the prevalence of AI in PWS children, further studies must be done.

Table 2. Summary of studies of adrenal insufficiency in PWS.

\begin{tabular}{|c|c|c|c|c|}
\hline Author(s) & Patient Group & Method & $\begin{array}{l}\text { Level Considered } \\
\text { Sufficient }\end{array}$ & Results \\
\hline Grugni et al., 2013 [24] & 53 PWS adults & $\begin{array}{l}\text { Low dose short } \\
\text { synacthen test. } \\
\text { Deficient patients } \\
\text { retested with high } \\
\text { dose short synacthen } \\
\text { test }\end{array}$ & $\begin{array}{l}\text { Peak cortisol response } \\
>500 \mathrm{nmol} / \mathrm{L}\end{array}$ & $\begin{array}{l}\text { After LDSST eight } \\
(15.1 \%) \text { had a PCR of } \\
<500 \mathrm{nmol} / \mathrm{L} \text {. On } \\
\text { retesting } 4 \text { showed } \\
\text { persistent suboptimal } \\
\text { response }(7.5 \%)\end{array}$ \\
\hline Corrias et al., 2012 [18] & $\begin{array}{l}84 \text { PWS children } \\
\text { ( } 35 \text { females and } \\
49 \text { males aged } \\
0.8-17.9 \text { years). }\end{array}$ & $\begin{array}{l}\text { Low-dose } \\
\text { tetracosactrin test } \\
1 \mu \mathrm{g} \text { and standard } \\
\text { dose tetracosactrin } \\
\text { test }(250 \mu \mathrm{g}) \text { in } \\
\text { second round of } \\
\text { testing }\end{array}$ & $\begin{array}{l}\text { Peak cortisol response } \\
>500 \mathrm{nmol} / \mathrm{L}\end{array}$ & $\begin{array}{l}12 \text { patients }(14.3 \%) \\
\text { had AI according to } \\
\text { LDSST but when } \\
\text { retested with SDSST } \\
\text { only } 4(4.8 \%) \text { were } \\
\text { confirmed AI }\end{array}$ \\
\hline Nyunt et al., 2010 [19] & $\begin{array}{l}\text { Randomly selected } \\
41 \text { PWS children } \\
\text { (mean age } 7.68 \\
( \pm 5.23) \text { years) }\end{array}$ & $\begin{array}{l}\text { Low dose synacthen } \\
\text { test }(1 \mu \mathrm{g})\end{array}$ & $\begin{array}{l}\text { Peak cortisol response } \\
>500 \mathrm{nmol} / \mathrm{L}\end{array}$ & $\begin{array}{l}\text { All children had a } \\
30 \mathrm{~min} \text { cortisol } \\
>500 \mathrm{nmol} / \mathrm{L}\end{array}$ \\
\hline $\begin{array}{l}\text { De Lind van } \\
\text { Wijngaarden } \\
\text { et al., } 2008 \text { [10] }\end{array}$ & $\begin{array}{l}25 \text { randomly selected } \\
\text { PICU patients, } \\
\text { median age } 9.7 \\
\text { (6.8-13.6 years) }\end{array}$ & $\begin{array}{l}\text { Overnight single dose } \\
(30 \mathrm{mg} / \mathrm{kg}) \\
\text { metyrapone test }\end{array}$ & $\begin{array}{l}\mathrm{ACTH}>33 \mathrm{pmol} / \mathrm{L} \text { at } \\
0730 \mathrm{~h}\end{array}$ & $\begin{array}{l}\text { Fifteen patients }(60 \%) \\
\text { had an insufficient } \\
\text { ACTH response }\end{array}$ \\
\hline Farholt et al., 2011 [23] & $\begin{array}{l}57 \text { patients with PWS } \\
\text { (mean age } 22 \text { years, } \\
\text { range } 0.5-48 \text { years) }\end{array}$ & $\begin{array}{l}\text { Standard high dose } \\
\text { synacthen test or } \\
\text { insulin tolerance test }\end{array}$ & $\begin{array}{l}\text { Peak cortisol } \\
\text { response }>500 \\
\text { nmol/L. Rise in } \\
\text { cortisol by } \\
\text { 250nmol/L }\end{array}$ & $\begin{array}{l}\text { All patients had a } \\
\text { normal response to } \\
\text { synacthen testing }\end{array}$ \\
\hline
\end{tabular}

\section{The Effects of GH on AI in PWS}

Adrenal insufficiency could also be iatrogenic in origin. Disruption of the HPA axis and growth hormone deficiency in PWS have been well documented with growth hormone therapy now in widespread use [25,26]. The AACE (American Association of Clinical Endocrinologists) guidelines for the use of GH therapy remind clinicians that GH can inhibit the enzyme $11 \beta$-hydroxysteroid dehydrogenase type 1 causing a shift in cortisol metabolism to favour cortisone production and, therefore, reduce global cortisol levels $[27,28]$. This may not have any clinical effect on most patients but it may unmask central hypothyroidism and hypoadrenalism. [29]. They recommend, therefore, that patients who become hypoadrenal on initiation of therapy should receive glucocorticoid replacement. 
Finally, it is known that GHD is associated with the development of other pituitary hormone deficiencies, including ACTH deficiency [30]. Surveillance for this is therefore recommended in cases of isolated GHD or cases with multiple pituitary hormone defects [30], suggesting that this should also be considered in patients with PWS.

\section{Summary and Conclusions}

Prader Willi syndrome is a congenital condition with a complex phenotype. It is clear that some association between PWS and AI appears to exist, although this may be a predominantly paediatric issue, as Farholt et al. demonstrated in 39 adult PWS subjects with a normal HPA axis [23]. Which PWS patients are most at risk of this remains unclear, as does how best to test for this worrying phenomenon. Having reviewed the current literature, we would advise that there is enough of a reported association for clinicians to have a low threshold for testing PWS for adrenal insufficiency and to treat according to the results and clinical picture. If there is clinical suspicion, it would be safer to treat with hydrocortisone, even if only during intercurrent illnesses or if severely unwell. Further research is required, however, to confirm what the mechanism behind $\mathrm{AI}$ is and which patients are most at risk and how best to monitor for this.

Author Contributions: O.S.E. performed the literature review and wrote the paper. A.K.L.-H. and M.G.S. reviewed drafts of the manuscript. All authors were involved in the idea for the paper and in the review and preparation of the final manuscript.

Conflicts of Interest: The authors declare no conflict of interest.

\section{References}

1. Prader, A.; Labhart, A.; Willi, H. Ein syndrome von adipositas, kleinwuchs, kryptorchismus und oligophrenie nach myotonieartigem zustand im neugeborenenalter. Schweiz. Med. Wochenschr. 1956, 86, 1260-1261.

2. Burman, P.; Ritzén, E.M.; Lindgren, A.C. Endocrine dysfunction in Prader-Willi syndrome: A review with special reference to GH. Endocr. Rev. 2001, 22, 787-799. [CrossRef] [PubMed]

3. Whittington, J.E.; Holland, A.J.; Webb, T.; Butler, J.; Clarke, D.; Boer, H. Population prevalence and estimated birth incidence and mortality rate for people with Prader-Willi syndrome in one UK Health Region. J. Med. Genet. 2001, 38, 792-798. [CrossRef] [PubMed]

4. Vogels, A.; van den Ende, J.; Keymolen, K.; Mortier, G.; Devriendt, K.; Legius, E.; Fryns, J.P. Minimum prevalence, birth incidence and cause of death for Prader-Willi syndrome in Flanders. Eur. J. Med. Genet. 2004, 12, 238-240. [CrossRef] [PubMed]

5. Crino, A.; di Giorgio, G.; Livieri, C.; Grugni, G.; Beccaria, L.; Bosio, L.; Corrias, A.; Chiumello, G.; Trifirò, G.; Salvatoni, A.; et al. A survey on Prader-Willi syndrome in the Italian population: Prevalence of historical and clinical signs. J. Pediatr. Endocrinol. Metab. 2009, 22, 883-893. [CrossRef] [PubMed]

6. Tuysuz, B.; Kartal, N.; Erener-Ercan, T.; Guclu-Geyik, F.; Vural, M.; Perk, Y.; Erçal, D.; Erginel-Unaltuna, N. Prevalence of Prader-Willi syndrome among infants with hypotonia. J. Pediatr. 2014, 164, 1064-1067. [CrossRef] [PubMed]

7. Lucas-Herald, A.; Perry, C.G.; Shaikh, M.G. Review of growth hormone therapy in adolescents and young adults with Prader-Willi syndrome. Expert Rev. Endocrinol. Metab. 2015, 10, 259-267. [CrossRef]

8. Deal, C.L.; Tony, M.; Hoybye, C.; Allen, D.B.; Tauber, M.; Christiansen, J.S.; 2011 Growth Hormone in Prader-Willi Syndrome Clinical Care Guidelines Workshop Participants. Growth Hormone Researc Society Workshop Summary: Consensus guidelines for recombinant human Growth Hormone therap in Prader-Willi syndrome. J. Clin. Endocrinol. Metab. 2013, 98, E1072-E1087. [CrossRef] [PubMed]

9. Bethin, K.E.; Muglia, L.J. Adrenal insufficiency. In Pediatric Endocrinology: A Practical Guide, 2nd ed.; Radovick, S., MacGillivray, M.H., Eds.; Humana Press: New York, NY, USA, 2013; pp. 199-221.

10. De Lind Van Wijngaarden, R.F.; Otten, B.J.; Festen, D.A.; Joosten, K.F.; de Jong, F.H.; Sweep, F.C.; Hokken-Koelega, A.C. High prevalence of central adrenal insufficiency in patients with Prader-Willi syndrome. J. Clin. Endocrinol. Metab. 2008, 93, 1649-1654. [CrossRef] [PubMed] 
11. Nagai, T.; Obata, K.; Tonoki, H.; Temma, S.; Murakami, N.; Katada, Y.; Yoshino, A.; Sakazume, S.; Takahashi, E.; Sakuta, R.; et al. Cause of sudden, unexpected death of Prader-Willi syndrome patients with or without growth hormone treatment. Am. J. Med. Genet. Part A 2005, 136, 45-48. [CrossRef] [PubMed]

12. Tauber, M.; Diene, G.; Molinas, C.; Hébert, M. Review of 64 cases of death in children with Prader-Willi syndrome (PWS). Am. J. Med. Genet. Part A 2008, 146, 881-887. [CrossRef] [PubMed]

13. Schrander-Stumpel, C.T.R.M.; Curfs, L.M.G.; Sasrowijoto, P.; Cassidy, S.B.; Schrander, J.J.P.; Fryns, J.P. Prader-Willi Syndrome: Causes of death in an international series of 27 cases. Am. J. Med. Genet. 2004, 124, 333-338. [CrossRef] [PubMed]

14. Stevenson, D.A.; Anaya, T.M.; Clayton-Smith, J.; Hall, B.D.; van Allen, M.I.; Zori, R.T.; Zackai, E.H.; Frank, G.; Clericuzio, C.L. Unexpected death and critical illness in Prader-Willi syndrome: Report of ten individuals. Am. J. Med. Genet. Part A 2004, 124, 158-164. [CrossRef] [PubMed]

15. Van Vliet, G.; Deal, C.L.; Crock, P.A.; Robitaille, Y.; Oligny, L.L. Sudden death in growth hormone treated children with Prader Willi syndrome. J. Pediatr. 2004, 144, 129-131. [CrossRef] [PubMed]

16. Miller, J.L.; Goldstone, A.P.; Couch, J.A.; Shuster, J.; He, G.; Driscoll, D.J.; Liu, Y.; Schmalfuss, I.M. Pituitary abnormalities in Prader-Willi syndrome and early onset morbid obesity. Am. J. Med. Genet. Part A 2007, 146, 570-577. [CrossRef] [PubMed]

17. Vermes, I.; Beishuizen, A. The hypothalamic-pituitary-adrenal response to critical illness. Best Pract. Res. Clin. Endocrinol. Metab. 2001, 15, 495-511. [CrossRef] [PubMed]

18. Corrias, A.; Grugni, G. Assessment of central adrenal insufficiency in children and adolescents with Prader-Willi syndrome. Clin. Endocrinol. (Oxf.) 2012, 76, 843-850. [CrossRef] [PubMed]

19. Nyunt, O.; Cotterill, A.M.; Archbold, S.M.; Wu, J.Y.; Leong, G.M.; Verge, C.F.; Crock, P.A.; Ambler, G.R.; Hofman, P.; Harris, M. Normal cortisol response on low-dose synacthen (1 microg) test in children with Prader Willi syndrome. J. Clin. Endocrinol. Metab. 2010, 95, E464-E467. [CrossRef] [PubMed]

20. Abdu, T.A.; Elhadd, T.A.; Neary, R.; Clayton, R.N. Comparison of the low dose short synacthen test (1 microg), the conventional dose short synacthen test ( $250 \mathrm{microg})$, and the insulin tolerance test for assessment of the hypothalamo-pituitary-adrenal axis in patients with pituitary disease. J. Clin. Endocrinol. Metab. 1999, 84, 838-843. [PubMed]

21. Weintrob, N.; Sprecher, E.; Josefsberg, Z.; Weininger, C.; Aurbach-Klipper, Y.; Lazard, D.; Karp, M.; Pertzelan, A. Standard and low-dose short adrenocorticotropin test compared with insulin-induced hypoglycemia for assessment of the hypothalamic-pituitary-adrenal axis in children with idiopathic multiple pituitary hormone deficiencies. J. Clin. Endocrinol. Metab. 1998, 83, 88-92. [CrossRef] [PubMed]

22. Agwu, J.C.; Spoudeas, H.; Hindmarsh, P.C.; Pringle, P.J.; Brook, C.G.D. Tests of adrenal insufficiency. Arch. Dis. Child. 1999, 80, 330-333. [CrossRef] [PubMed]

23. Farholt, S.; Sode-Carlsen, R.; Christiansen, J.S.; Ostergaard, J.R.; Hoybye, C. Normal cortisol response to high dose synacthen and insulin tolerance test in children and adults with Prader-Willi syndrome. J. Clin. Endocrinol. Metab. 2011, 96, E173-E180. [CrossRef] [PubMed]

24. Grugni, G.; Beccaria, L.; Corias, A.; Crino, A.; Cappa, M.; de Medici, C.; di Candia, S.; Gargantini, L.; Ragusa, L.; Salvatoni, A.; et al. Central adrenal insufficiency in young adults with Prader-Willi Syndrome. Clin. Endocrinol. 2013, 79, 371-378. [CrossRef] [PubMed]

25. Götherström, G.; Bengtsson, B.A.; Bosaeus, I.; Johannsson, G.; Svensson, J. A 10-year, prospective study of the metabolic effects of growth hormone replacement in adults. J. Clin. Endocrinol. Metab. 2007, 92, 1442-1445. [CrossRef] [PubMed]

26. Simpson, H.; Savine, R.; Sönksen, P.; Bengtsson, B.A.; Carlsson, L.; Christiansen, J.S.; Clemmons, D.; Cohen, P.; Hintz, R.; Ho, K.; et al. Growth hormone replacement therapy for adults: Into the new millennium. Growth Horm. IGF Res. 2002, 12, 1-33. [CrossRef] [PubMed]

27. Agha, A.; Walker, D.; Perry, L.; Drake, W.M.; Chew, S.L.; Jenkins, P.J.; Grossman, A.B.; Monson, J.P. Unmasking of central hypothyroidism following growth hormone replacement in adult hypopituitary patients. Clin. Endocrinol. (Oxf.) 2007, 66, 72-77. [CrossRef] [PubMed]

28. Toogood, A.A.; Taylor, N.F.; Shalet, S.M.; Monson, J.P. Modulation of cortisol metabolism by low-dose growth hormone replacement in elderly hypopituitary patients. J. Clin. Endocrinol. Metab. 2000, 85, 1727-1730. [CrossRef] [PubMed] 
29. Cook, D.; Yuen, K.; Biller, B.; Kemp, S.; Vance, M. American Association of Clinical Endocrinologists medical guidelines for clinical practice for growth hormone use in growth hormone-deficient adults and transition patients-2009 update. Endocr. Pract. 2009, 15, 1-29. [CrossRef] [PubMed]

30. Blum, W.E.; Deal, C.; Zimmermann, A.G.; Shavrikova, E.P.; Child, C.J.; Quigley, C.A.; Drop, S.L.; Cutler, G.B., Jr.; Rosenfeld, R.G. Development of additional pituiary homone deficiencies in pediatric patients orginall diagnosed with idiopathic isolated GH deficiency. Eur. J. Endocrinol. 2014, 170, $13-21$. [CrossRef] [PubMed]

(C) 2016 by the authors; licensee MDPI, Basel, Switzerland. This article is an open access article distributed under the terms and conditions of the Creative Commons by Attribution (CC-BY) license (http://creativecommons.org/licenses/by/4.0/). 